Article

\title{
Implementation of Website Marketing Strategies in Sports Tourism: Analysis of the Online Presence and E-Commerce of Golf Courses
}

\author{
Natalia Daries, Eduard Cristobal-Fransi * (D) and Berta Ferrer-Rosell \\ Department of Business Management, Faculty of Law, Economics and Tourism, University of Lleida, \\ 25001 Lleida, Spain; natalia.daries@udl.cat (N.D.); berta.ferrer@udl.cat (B.F.-R.) \\ * Correspondence: eduard.cristobal@udl.cat
}

Received: 19 October 2020; Accepted: 5 December 2020; Published: 9 December 2020

check for updates

\begin{abstract}
As a sports activity with immense tradition, current offerings and future prospects, golfing represents a first-rate tourist resource. In choosing golfing destinations, tourists rely upon information that is available online, just as consumers do in making decisions about any resource. Thus, in our study, we sought to profile the internet presence of golf courses in Catalonia, as well as the maturity of their e-commerce. To that end, we developed an integrated model for analysing the websites of golf courses: one based on web content analysis and structured with four dimensions (i.e., information, communication, e-commerce and additional functions) and the phases of the extended model of internet commerce adoption (eMICA). Applied to all golf courses in Catalonia that operate websites, the model revealed that, despite the sport's great importance to the local economy and tourism, the golf courses do not have an adequate online presence or sufficient platforms for communication. The present work includes information on its theoretical contribution, implications for management, limitations and future lines of research.
\end{abstract}

Keywords: golf courses; sports tourism; e-commerce; web content analysis; eMICA

\section{Introduction}

The use and diffusion of information and communication technologies (ICTs), in transforming society in general and commercial organisations in particular, have given rise to so-called "information societies" [1]. Consequently, research on adopting ICTs has aroused great interest among scholars in various fields, especially business [2-4]. To date, such studies have shown ICTs' contribution to the competitive advantage of organisations that have implemented them in terms of their productivity [5], internationalisation [6,7], performance in the labour market [8] and ability to continue being competitive $[9,10]$.

Hofacker and Belanche [11] have argued that a top reason companies use the internet and social media networks in their marketing strategies is to enhance their contact with clients and provide an important source of information to them. ICTs also provide organisations with better access to markets, both nationally and internationally [12,13], because e-commerce, by eliminating the geographical barriers at play in traditional commerce, reduces transaction costs and facilitates worldwide connections between users [14]. For those reasons, implementing ICTs is pivotal for organisations and companies in general, even in the tourism industry.

Against that background, we analysed the online presence of all golf courses in Catalonia that operate websites, as well as the maturity of their e-commerce, for two major reasons. The first reason is the tourism industry's importance to the economies of Spain and Catalonia. According to the statistics of Tourist Movements at Borders [15], Spain received an annual average of more than 60 million tourists 
between 2004 and 2018 and, in 2018, welcomed a record of more than 82.6 million. That year, receiving 19.1 million of those tourists, Catalonia was the premier tourist destination in Spain. Moreover, during that same 14-year period, as revealed by the Tourism Expenditure Survey [16], the annual spending of international tourists in Spain slightly exceeded $€ 57,000$ million on average and reached $€ 90,000$ million in 2018. As a sector, tourism contributed $€ 178,000$ million to Spain's economy in 2018 and thus accounted for $14.6 \%$ of its GDP, according to data from the World Travel and Tourism Council [17].

The second reason is the importance of golf courses to tourism, particularly in Spain. According to Aymerich and Anabitarte [18], Spain has 359 golf courses, 40 of which are in Catalonia, and each year welcomes nearly 278,000 golfers. In turn, employing more than 11,000 workers, golf in Spain has an overall annual economic impact of $€ 2.07$ billion. Worldwide, the market for golf tourism is worth more than USD 17 billion, according to the International Association of Golf Tour Operators, and the number of people who play golf each year stands at 56 million. Of them, an estimated 10\% travel abroad each year with the main objective of playing golf, for an international golf tourism market encompassing approximately 5.6 million players [19].

For people who engage in sports in general and for golf tourists in particular, websites are critical tools for accessing logistical information before arriving at sporting facilities [20]. Consequently, it is important for researchers to elucidate how golf courses communicate information about the services that they offer and about accommodations, transport services and other tourist resources in the area [21]. It is even relevant to study an aspect as current as the communication of sustainability policies in golf courses [22]. Meanwhile, for the golf courses, having an optimal online reservation system is essential to providing more competitive prices and differentiating the attraction's service offerings from those of competitors [23].

Considering all of the above, we recognised the need to investigate golf courses' use of the internet and e-commerce, especially in the context described, and analyse their use of ICTs and thereby identify the chief factors that determine their online behaviours. Thus, our study's overarching objective was to analyse whether golf courses in Catalonia, as demonstrated by their websites, are taking advantage of the internet's full range of possibilities. As exploratory research, our study was expected to help us to determine the extent to which such facilities currently use their websites. Despite the value of that knowledge, few studies have involved examining those aspects in such detail in the golf and sports tourism sector, especially not from a marketing perspective.

With that overarching objective in mind, we established three subordinate objectives. First, we set out to propose an integrated model for assessing the online presence of golf courses in four content-related categories (i.e., information, communication, e-commerce and additional functions) and, using the extended model of internet commerce adoption (eMICA), analyse the maturity of their e-commerce. Second, we aimed to use the proposed model to analyse the websites of all golf courses in Catalonia with an online presence. Third and last, after analysing their use of ICTs in marketing and communicating with clients on their websites, we wanted to provide practical recommendations for how the golf courses can manage their online presence more efficiently.

\section{Golf and the Tourist Industry}

Modern tourists demand more active experiences on their vacations and in their leisure time, largely due to growing interest in personal health and well-being and the enjoyment of outdoor activities such as sports in natural settings. Therefore, promoting that type of sporting activity can generate important tourist resources for particular destinations $[24,25]$. In that context, a major tourist activity is golf tourism, defined by Hudson and Hudson [26] as golf played by tourists away from their primary residences for noncommercial purposes. Golf tourism involves services provided by travel agencies that specialise in planning and providing golf tourism products [27].

Of course, golf tourism involves not only visiting golf courses away from one's primary residence but also participating in other leisure activities at the destination and visiting local tourist attractions [28-30]. In literature on the subject, a widely examined element has been the destination image surrounding golf 
courses [27,31,32]. Meanwhile, some researchers, especially in segmentation research, have focused on identifying the characteristics of golf tourists [33-36], whereas others have focused on identifying their behaviours. Among them, Humphreys [37] observed that participating in golf tourism is driven by satisfaction and positive experiences, whereas Stebbins [38] found that attitude is an important predictor of engaging in that type of activity.

In other work, Kim and Ritchie [39] differentiated three types of golf tourists: intensive golfers, golfers with multiple motivations and golf companions. The first are tourists whose primary purpose in travelling was to play golf and who often purchase specific golf-oriented packages. The second group are tourists who participate in nongolfing activities. Last, the third category, as the description suggests, are tourists who accompany golfers and sometimes also participate in the game. By some contrast, Hennessey et al. [33] have categorised golf tourists by frequency of engagement-as dedicated, moderate or infrequent golfers-each of which exhibits significant behavioural differences based on how often they play the game. Those findings on golfers' motivations and behaviours reflect the general conclusions drawn by Gibson and Pennington-Gray [40], who used role theory to describe and explain the behaviour of sports tourists, particularly golf tourists.

Like most tourists, golf tourists are subject to a series of factors that influence their decisions to travel and their selection of specific destinations [41]. Regarding the latter, Humphreys [37] has identified six such factors: vacation design, emotional travel rewards, total expenditure, related services and facilities, the characteristics of the golf course and the reputation of the destination.

Despite literature on the mentioned topics, few studies seem to have been conducted on golf courses' online presence and internet use. Among them, a study by Powers and Tabibzadeh [42], conducted to analyse the online marketing of golf courses in the U.S. state of Kentucky revealed that, though the vast majority of courses have some sort of web presence, their websites play a primarily promotional or informational role. Similarly, in a comparative study examining golf courses in Portugal, Spain and the United States, Afonso and Martínez-López [43] analysed their internet use for promotional purposes. Meanwhile, García-Tascón and Pradas García [44] studied the transparency of golf course websites in Andalusia, Spain. By contrast, Park et al. [34] conducted a content analysis of South Korean golf tourist blogs to identify attributes associated with seven destinations in mainland China.

In other work, Brooksbank, Garland and Werder [45] have shown that good strategic marketing planning that includes digital media can improve the long-term viability of golf courses. They defined strategic marketing as an ongoing, organisation-wide, customer-led planning approach that facilitates optimal organisational responses to the environment. After investigating 10 basic strategic marketing practices and their relationships with competitive business performance, those authors discovered that although most golf courses had adopted strategic marketing, higher-performing ones had placed far greater emphasis on each of the 10 practices [45]. As other authors have shown, strategic marketing planning typically consists of five steps: conducting a comprehensive strategic situation analysis, developing marketing objectives, formulating a marketing strategy, organising for marketing and using strategic control procedures [46]. In somewhat related research, Pereira et al. [47] analysed promotional texts on golf-related websites as sources for identifying brand personality traits.

Given golf tourism's impact in Spain, the changes and needs of modern society and the importance for organisations to manage their websites, it is valuable to understand what type of online presence golf courses in Spain have and what use they make of the different digital marketing elements available online.

\section{Methods}

An organisation's website plays a fundamental role as an organ of institutional communication and is key in representing the organisation as an entity. Together with other elements, such as social media, online video and email, it is also a principal part of the design of digital communication campaigns [48]. Therefore, developing a methodology for identifying and evaluating the characteristics that websites should possess to be ideal means of communication with clients is of great interest to 
researchers and practitioners alike. However, as several authors have affirmed, no universally accepted methodology for evaluating websites is currently available [49-52].

If we focus on analysis, many studies refer to a set of indicators that can be grouped into four large groups: technical, commercial, content-related, and design-related [53-55]. In turn, we adopted a perspective focused on market orientation, from which websites are evaluated according to their focus on users as potential customers. In that way, evaluators pay special attention to aspects related to the promotion of activities, online transactions and both product and service characteristics [56].

The model proposed in our work combines the eMICA and web content analysis (WCA) adapted for golf courses (Figure 1). The variables used to gauge the adoption of e-commerce by the golf courses' websites were adapted from the eMICA and selected based on our literature review. In turn, we decided that, in moving between levels and to consolidate their positions, the websites had to exhibit a minimum number of attributes [56-58]. Thus, the sites advanced to the next level if they contained all of the variables at the previous level. The scale was dichotomous for all variables.

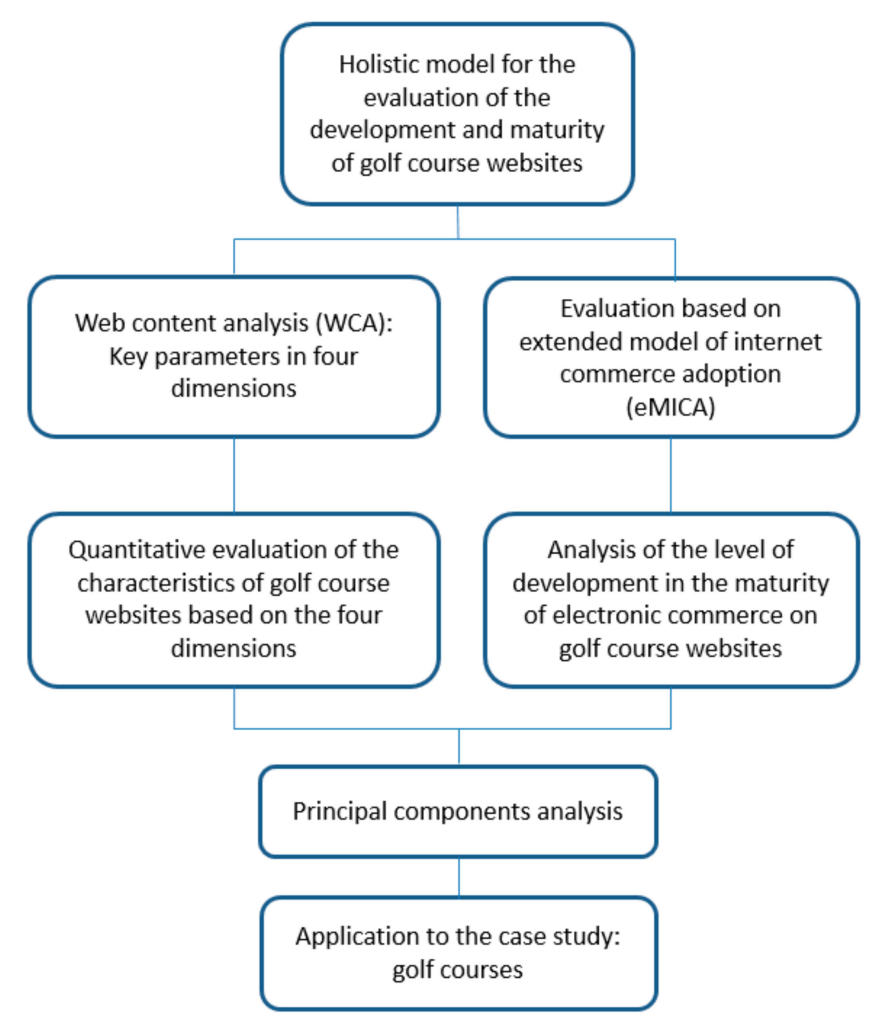

Figure 1. Study process design.

Our analysis focused on the websites of golf courses in Catalonia. To fulfil the proposed objectives, we analysed the websites of all golf courses that are members of the Catalan Golf Federation. After discarding the three golf courses without websites, 37 sites remained for analysis-27 courses with 18 holes and 10 courses with 9 holes-meaning that $92.5 \%$ of golf courses in Catalonia have an online presence. The main objective of our work was to analyse how they use that presence.

\subsection{Web Content Analysis (WCA)}

We conducted an exhaustive review of the literature with the aim of developing a dimensional model for structuring our WCA for the golf courses [50,56,59-63]. The model was designed to highlight the resources that golf courses offer on their websites to help users obtain the information that they need and to foster client-company interaction, whether to carry out e-commerce activities (e.g., selling products and contracting services or lessons) or to discuss issues on a secure platform that complies with website quality standards. 
Our proposed website analysis model is structured in four blocks: information, communication, e-commerce and additional functions (Table 1). Each block comprises characteristics subjected to evaluation, and the evaluation indicators for the different dimensions are listed as well.

Table 1. Dimension items.

\begin{tabular}{|c|c|}
\hline Information Variable & $\begin{array}{l}\text { 1. Basic golf course information } \\
\text { I.1.1- Golf course description (address, membership information, origin, history, etc.). } \\
\text { I.1.2- Contacts: telephone, fax numbers and email address. } \\
\text { I.1.3- Images of the golf course. } \\
\text { I.1.4- Visual and textual information about services on offer. } \\
\text { I.1.5- News/events communications. } \\
\text { I.1.6- Golf course location information. } \\
\text { I.1.8- Virtual tour. } \\
\text { I.1.7- Links to assessment websites of services provided by the golf course. } \\
\text { I.1.9- Golf course opening hours. } \\
\text { 2. Golf course facilities } \\
\text { I.2.1- Plan of the golf course. } \\
\text { I.1. } \\
\text { I.2.2- Booking of rounds of golf on the official website. } \\
\text { I.2.4- Golf lesson information; lessons for adults/children. } \\
\text { 3. Local environment of the golf course } \\
\text { I.3.1- Tourist information about the area. } \\
\text { I.3.2- Weather reports. } \\
\text { 4. Promotions } \\
\text { I.4.1- Event promotions, advertising campaigns, news, banners, fairs, promotional calendar and } \\
\text { events on the golf course. } \\
\text { I.4.2- Incentives: vouchers/coupons, exclusive internet offers, online contests, promotion of } \\
\text { different services. }\end{array}$ \\
\hline Communication Variable & 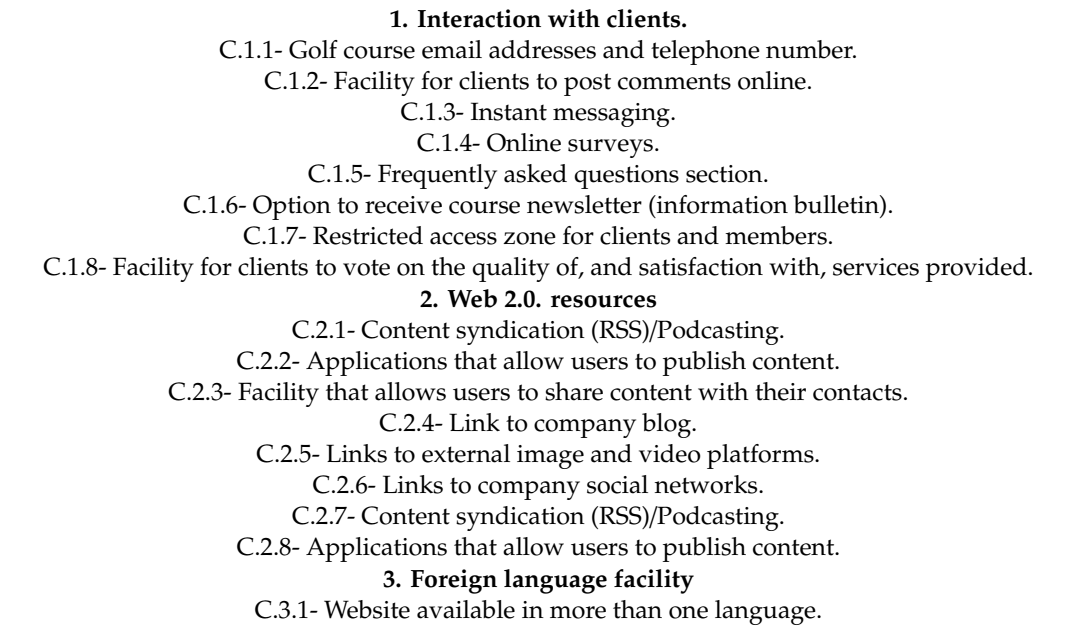 \\
\hline Electronic Commerce Variable & $\begin{array}{l}\text { EC.1- Online payment. } \\
\text { EC.2- Secure online transactions (in purchase processes, digital signatures, encryption, security } \\
\text { code via mobile text). } \\
\begin{array}{c}\text { EC.3- Interaction with the server: database consultation (customer access to their profiles, with the } \\
\text { possibility of making modifications, access to purchase history, etc.) }\end{array}\end{array}$ \\
\hline Additional Functions Variable & $\begin{array}{l}\text { 1. Information security. } \\
\text { AF 1.1. Privacy policy and legal notice } \\
\text { AF 1.2. Data protection laws } \\
\text { AF 1.3. Website security } \\
\text { 2. Certifications. } \\
\text { AF 2.1- Golf Environment Organisation (GEO) certification. A seal granted by the Golf } \\
\text { Environment Organisation } \\
\text { AF 2.2- Environmental Management Systems (EMS) help to identify, prioritise and manage } \\
\text { environmental risks. } \\
\text { AF 2.3- Environmental certification (ISO 14000). Environmental policy established by the } \\
\text { Directorate of the National Golf Centre } \\
\text { AF 2.4- Other certifications. } \\
\text { 3. Mobile version. } \\
\text { AF 3.1- Possession of an internet link to the mobile version of the website. } \\
\text { AF 3.2- Availability of official golf course app. }\end{array}$ \\
\hline
\end{tabular}


As mentioned, to achieve our overarching objectives, we evaluated the websites from a marketing perspective. After identifying the online content and services offered on the websites, we analysed the informative content and interactive services considered to be useful or attractive to users $[56,61]$. The items were chosen from the literature review, and new elements were added to them to accommodate the context of golf courses.

During field work, conducted in April and May 2019, we used the proposed model to prepare a template containing the various aspects chosen for examination following the literature review. Ultimately, the template consisted of 46 indicators (i.e., items) for analysing the dimensions of the information, communication, e-commerce and additional functions of the golf courses' websites.

Content analysis from a quantitative perspective was performed to assess the online presence, level of information and interactivity of the websites [54,56,61]. Following Neuendorf [64], our content analysis involved eight steps. First, to formulate research questions, we considered that the websites that had adopted e-commerce to a more advanced degree would make greater use of different web-based possibilities. Second, we identified variables related to the information, communication, e-commerce and additional functions afforded by the websites. Third, we defined categories and units of measurement for analysing all of the websites, which involved identifying the unit of analysis (i.e., the golf course in Catalonia) and defining the categories-that is, the different items that determine the web presence of such golf courses. Fourth, to create the coding scheme, we produced a code book containing the categories and how they were measured. All items were included in the four mentioned dimensions (i.e., information, communication, e-commerce and additional functions). Fifth, for sampling, we selected websites belonging to golf courses in Catalonia. Sixth, the code book was tested by two trained coders who evaluated the websites, and seventh, coding for the sample was performed independently with reference to the code book. Eighth and last, data were analysed by evaluating the presence or absence of certain characteristics and aggregating the data in tables and graphs.

\subsection{Extended Model of Internet Commerce Adoption (eMICA)}

Burgess and Cooper [65] developed the model of internet commerce adoption (MICA) while studying the metal fabrication industry in Australia. The MICA maintains that when developing commercial websites, companies usually begin with a simple webpage and that their online presence becomes more complex as it incorporates new processes due to increased experience with and knowledge about ICTs. Representing three levels of business processes, the model consists of three corresponding stages: (a) web-based promotion, (b) the provision of information and services and (c) transaction processes. Those stages provide roadmaps that indicate the level of the development of e-commerce applications in various business sectors-in our case, golf tourism. Beyond that, acknowledging that websites continually evolve, the MICA postulates different stages of development, from inception (i.e., promotion) through consolidation (i.e., provision) until reaching maturity (i.e., processing). It also includes levels of website complexity and functionality that reflect the evolution of companies as they develop from having a static presence online to having a dynamic website, usually by increasing levels of interactivity, incorporating value chain integration and hosting innovative applications that add value in terms of information management and functionality [66,67].

Since its creation, the MICA has been applied in sectors other than manufacturing, especially in the tourism industry [68-72] but also in sports facilities management [55,73-75]. In the process, as improvements to the model were made and several layers of sophistication added, the MICA morphed into the eMICA to accommodate new virtual environments and the particularities of the internet (Table 2). In brief, the eMICA prescribes a phased evaluation that allows websites to be assessed from the promotional level to higher-level transactional processes. The model does have its limitations, however. As Schmidt et al. [76] have argued, the eMICA tends to reduce the complexity of research, and it can position websites at two developmental levels at the same time or at no levels whatsoever. Nevertheless, because our goal, after adapting the model, was to assess the maturity of the 
golf courses' websites, the eMICA was deemed suitable because it contains the logical dimensions that a website, as a technology platform, should have: information, communications and transactions [77].

In using the eMICA, we considered that companies in sports tourism, despite being important tourist resources for their destinations, do not always take advantage of all possibilities offered by ICTs [78]. In our case, as studies have indicated, the websites of golf courses rarely incorporate advanced functions that maintain relationships with customers and are not used for communication, which precludes the possibility of enjoying greater client-company interactivity [79].

Table 2. Phases of evaluation.

\begin{tabular}{|c|c|}
\hline $\begin{array}{c}\text { Phase 1: } \\
\text { Promotion(Information) }\end{array}$ & Level 1: Basic Information (Minimum of 3 of the 5 Proposed Variables) \\
\hline & $\begin{array}{l}\text { Contact details: Golf course name, address, telephone and fax numbers, and others } \\
\text { Opening days and hours } \\
\text { Plan of the golf course } \\
\text { Photographs of the golf course } \\
\text { Location information } \\
\text { Eevel 2: Rich information (minimum of } 4 \text { of the } 7 \text { proposed variables) } \\
\text { Email and/or contact form } \\
\text { Weather forecasts } \\
\text { Website available in more than one language } \\
\text { Quality awards and certifications } \\
\text { News/events information } \\
\text { Internet-based promotions and incentives (vouchers/coupons, exclusive internet offers, } \\
\text { online contests) }\end{array}$ \\
\hline $\begin{array}{c}\text { Phase 2: } \\
\text { Provision (Dynamic Information) }\end{array}$ & 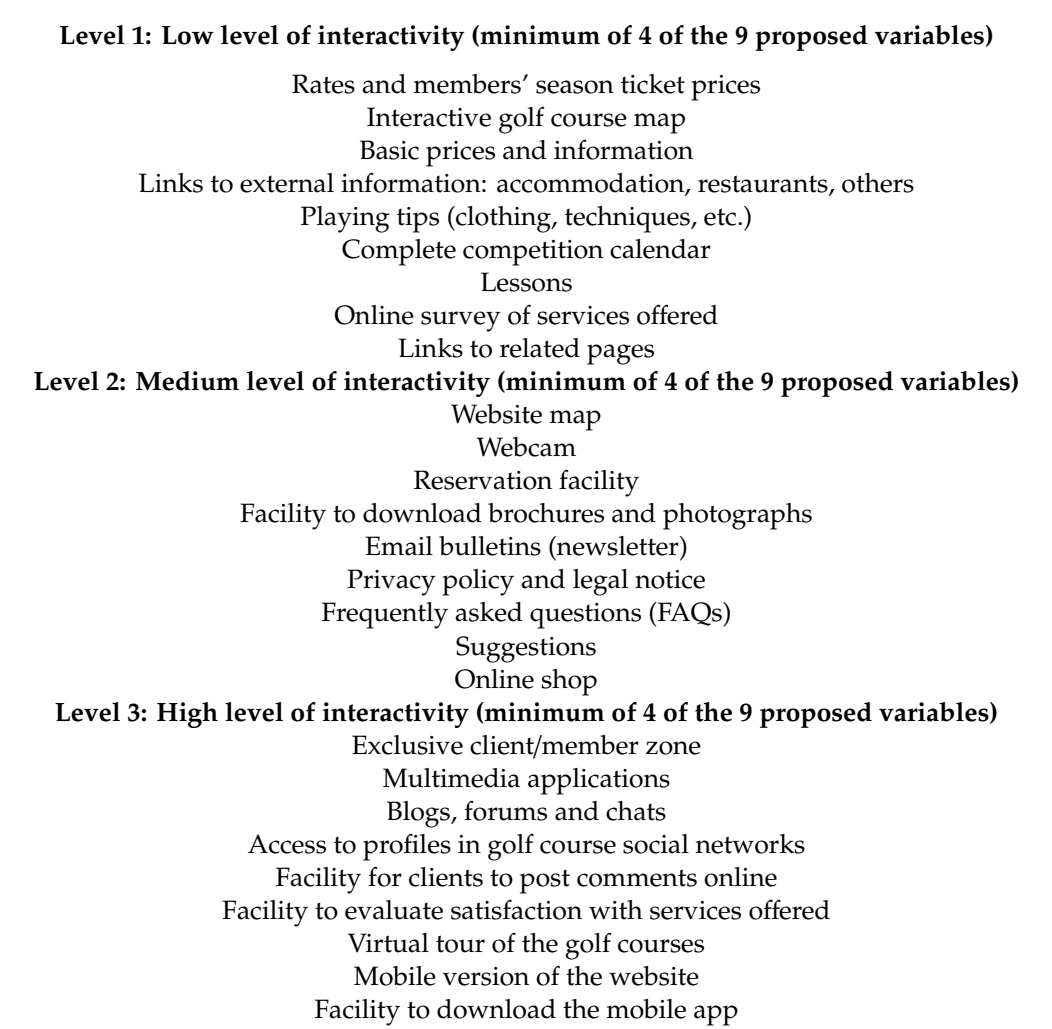 \\
\hline $\begin{array}{c}\text { Phase 3: } \\
\text { Processing (Functional Maturity) }\end{array}$ & $\begin{array}{l}\text { Secure online transactions, (in purchase processes, digital signatures, encryption, security } \\
\text { code via mobile text) (secure forms of payment using credit/debit cards or PayPal) } \\
\text { Interaction with the server: database consultation (access to customer profiles with the } \\
\text { possibility of modification, access to purchase history, etc.). Private registration area }\end{array}$ \\
\hline
\end{tabular}




\subsection{Integration of the eMICA and WCA}

After applying the two methods, we extracted the results of the proposed integrated model-that is, we combined the items of the eMICA and the dimensions of WCA. Again, our aim was to establish and compare the golf courses' web content and technological maturity or, in other words, to compare the overall experience and complexity of the websites. First, the relationship between the levels of the eMICA attained and the means of the items of the WCA dimensions were calculated. To do so, we compared the means by type of golf course determined by an analysis of variance (ANOVA). Once the relationships between the levels of the eMICA and the dimensions of the WCA were analysed, the ANOVA was complemented by a principal component analysis (PCA), a multivariate method of interdependence analysis applied to a dataset with numerical variables. PCAs are useful for reducing the set of variables to a small number of synthetic components or factors with minimal loss of information. In our analysis, the variables were the sum of the items (i.e., frequency) of each dimension of the WCA and the levels of the eMICA for each golf course's website. SPSS version 20.0 was used for all analyses.

\section{Results}

\subsection{Results of the WCA}

Table 3 sets out the percentage of the golf courses' websites that incorporate elements of the WCA, the level of presence of each item and the statistical significance and power (i.e., V of Cramer) of the relationship between the type of golf course and item analysed.

Table 3. Information indicators (I) with percentages by type of golf course.

\begin{tabular}{|c|c|c|c|c|}
\hline Information & 18 Holes & 9 Holes & Total & V.C. and Sig. \\
\hline I.1.1- Description of the golf course & 100 & 100 & 100 & - \\
\hline I.1.2- Contacts: telephone and fax numbers, email address & 100 & 100 & 100 & - \\
\hline I.1.3- Images of the golf course & 100 & 100 & 100 & - \\
\hline I.1.4- Text and visual information about services offered & 96.3 & 100 & 97.3 & 0.101 \\
\hline I.1.6- Information on the location of golf courses & 100 & 100 & 100 & - \\
\hline I.1.7- Links to assessment websites of services provided by the golf course & 18.5 & 0.0 & 13.5 & 0.241 \\
\hline I.1.8. Virtual tours & 7.4 & 0.0 & 5.4 & 0.145 \\
\hline I.1.9. Golf course opening hours & 48.1 & 60.0 & 51.4 & 0.105 \\
\hline I.2.1- Golf course plans & 96.3 & 80.0 & 91.9 & 0.251 \\
\hline I.2.2- Facility to book rounds of golf & 81.5 & 50.0 & 73.0 & $0.315^{*}$ \\
\hline I.2.3- Price information & 96.3 & 20.0 & 75.7 & $0.790^{* *}$ \\
\hline I.2.4- Golf lesson information: courses for adults/children & 100 & 100 & 100 & - \\
\hline \multicolumn{5}{|l|}{ 3. Golf course surroundings } \\
\hline I.3.1- Local area tourism information & 40.7 & 20.0 & 35.1 & 0.193 \\
\hline I.3.2- Weather forecasts & 40.7 & 30.0 & 37.8 & 0.098 \\
\hline I.3.3- Access routes to the golf course & 81.5 & 60.0 & 75.7 & 0.222 \\
\hline
\end{tabular}

Sig: 0.01; ${ }^{*}$ Sig: $0.05 ;{ }^{* *}$ Sig: 0.001. 


\subsubsection{Information}

The dimension of information analysed the mechanisms through which the golf courses use their websites to communicate information about their chief characteristics, facilities and environments as well as to promote their products. As shown in Table 3, information about the golf courses (I.1) and their facilities (I.2) achieved higher scores than information provided about their environments (I.3) and their promotions (I.4). Information was particularly lacking in the local environment, especially tourist information and weather forecasts. Among other results, the websites for 18-hole courses provided more information than the ones for nine-hole courses. We can conclude, therefore, that information disseminated through websites is evaluated differentially based on the category under analysis. In first place is information about the golf course, in second place is information about facilities and, in third and fourth place (interchangeably), information about the environment and promotions. Last, the presence of some aspects of digital marketing was minimal, including virtual tours (I.1.8) at 5.4\% of the total and links to assessment websites (I.1.7) at 13.5\%.

\subsubsection{Communication}

The dimension of communication consisted of tools that promote company-client interaction on the golf courses' websites and other digital marketing elements, as well as measures whether the content is offered in more than one language. As shown in Table 4, items related to company-client interaction (e.g., use of instant messaging and use of social media networks) differed significantly depending on the type of golf course, especially among the 18-hole courses. At the same time, the 18-hole courses used the internet far more than their nine-hole counterparts.

Table 4. Communication indicators (C) with percentages by type of golf course.

\begin{tabular}{|c|c|c|c|c|}
\hline Communication & 18 Holes & 9 Holes & Total & V.C. and Sig. \\
\hline \multicolumn{5}{|l|}{ 1. Client interaction } \\
\hline C.1.1- Golf course email address and telephone number & 100 & 100 & 100 & - \\
\hline C.1.2- Facility for clients to post comments online & 81.5 & 10.0 & 62.2 & $0.655^{* *}$ \\
\hline C.1.3- Instant messaging & 81.5 & 0.0 & 59.5 & $0.737^{* *}$ \\
\hline C.1.4- Online surveys & 0 & 0 & 0 & - \\
\hline C.1.5- Frequently asked questions area & 22.2 & 0 & 16.2 & 0.268 \\
\hline C.1.6- Information bulletin & 66.7 & 50.0 & 62.2 & 0.153 \\
\hline C.1.7- Private client/member zone & 22.2 & 0 & 16.2 & 0.268 \\
\hline $\begin{array}{l}\text { C.1.8- Facility for clients to vote on the quality of, and } \\
\text { satisfaction with, services provided }\end{array}$ & 0 & 0 & 0 & - \\
\hline \multicolumn{5}{|l|}{ 2. Website resources } \\
\hline C.2.1- Content syndication (RSS)/Podcasting & 29.6 & 20.0 & 27.0 & 0.096 \\
\hline C.2.2- Applications that allow users to publish content & 0 & 0 & 0 & - \\
\hline C.2.3- Facility to share content with friends and contacts & 0 & 10.0 & 2.70 & $0.274^{\wedge}$ \\
\hline C.2.4- Link to company blog & 11.1 & 10.0 & 10.8 & 0.016 \\
\hline C.2.5- Links to external image and video platforms & 33.3 & 0 & 24.3 & $0.345^{*}$ \\
\hline C.2.6- Links to company social networks & 74.1 & 30.0 & 62.2 & $0.404^{*}$ \\
\hline \multicolumn{5}{|l|}{ 3. Language capabilities } \\
\hline C.3. Website available in more than one language & 81.5 & 50.0 & 73.0 & $0.315^{\wedge}$ \\
\hline
\end{tabular}

^ Sig: 0.01; * Sig: $0.05 ;{ }^{* *}$ Sig: 0.001 . 
In general, the most common means of company-client communication was over the phone and email (C.1.1), which all of the websites offered, followed by online comment boards (C.1.2) and newsletters (C.1.6). Remarkably, no website offered a way to assess the quality of services provided or conducted online surveys, and online interactivity scored less than company-client interaction. In that case, the use of social media networks stood out (C.2.6), with a score of $62.2 \%$, whereas the scores for the other items were significantly less. For example, only $2.7 \%$ of the websites offered content sharing (C.2.3), and only $10.8 \%$ had their own blogs.

To complement the analysis of the communication variables, we examined the websites' capacity to present information in different languages. Overall, information was presented in more than one language on the websites, albeit not to a meaningful extent. Some $73 \%$ of the sites offered their content in two or more languages, largely depending upon the size of their golf courses. The vast majority of the websites for the 18-hole courses ( $81.5 \%$ ) operated in multiple languages compared to only half of the nine-hole courses (50\%). Such data are important because, according to Aymerich and Anabitarte [18], the impact of the golf industry on Spain's economy is $€ 2.07$ billion, with $€ 564$ million directly attributed to tourism. Although golf courses that present relevant information in multiple languages on their websites will enjoy a clear competitive advantage in attracting tourists, nearly $40 \%$ of the courses analysed have made the obvious mistake of having monolingual websites.

\subsubsection{E-Commerce}

The dimension of e-commerce captured the availability of online payment services, secure online transactions and interactions with the server on the golf courses' websites (see Table 5). The analysis identified a stark difference in the implementation of digital business elements based on the type of golf course. Those elements were significantly present on the websites of 18-hole courses (70.4\%) in the three subsections EC1, EC2 and EC3 but entirely absent on the websites of the nine-hole courses. Overall, $51.4 \%$ of the golf courses analysed featured those three items on their websites.

Table 5. E-commerce (EC) indicators with percentages by type of golf course.

\begin{tabular}{ccccc}
\hline Electronic Commerce & 18 Holes & 9 Holes & Total & V.C. and Sig. \\
\hline $\begin{array}{c}\text { EC.1- Online payment } \\
\text { EC.2- Secure online transactions (in purchase }\end{array}$ & 70.4 & 0.0 & 51.4 & $0.625^{* *}$ \\
\cline { 2 - 5 } $\begin{array}{c}\text { Exocesses, digital signature, encryption, security code } \\
\text { via mobile text) }\end{array}$ & 70.4 & 0.0 & 51.4 & $0.625^{* *}$ \\
\cline { 2 - 5 } $\begin{array}{c}\text { EC.3- Interaction with the server: database } \\
\text { consultation (access to client profile with the facility } \\
\text { to modify, access to purchase history, etc.) }\end{array}$ & 70.4 & 0.0 & 51.4 & $0.625^{* *}$ \\
\hline
\end{tabular}

^Sig: 0.01; * Sig: 0.05; ** Sig: 0.001 .

\subsubsection{Additional Functions}

The dimension of additional functions (Table 6) included general aspects considered relevant to include on websites for golf courses in three fundamental categories: information security, quality certification and the availability of a mobile version of the website. Ultimately, the dimension showed behavioural results similar to the others. Scores for privacy policies and legal notices (AF.1.1) were $67.6 \%$, whereas the score for the availability of information about data protection laws (AF.1.2) was $56.8 \%$ overall and only $30 \%$ for the websites of nine-hole courses. Not only is that figure significantly low, but it also indicates that an important percentage of websites, by means of registration processes, have gained access to clients' or partners' information and thus not complied with data protection laws. Along similar lines, only $40 \%$ of the websites provided information about their privacy policies. Beyond that, few of the websites advertised or at least displayed that their courses had quality certifications; only $7.4 \%$ of websites for the 18-hole courses indicated having certification from the Golf Environment Organization, and only 3.7\% indicating having environmental certifications. Tellingly, no website for 
a nine-hole course displayed information about certification. Last, $75.7 \%$ of the sites provided links to their mobile versions (FA 3.1), although far fewer (10.8\%) indicated having an official mobile app (AF 3.2).

Altogether, the analysis of those four dimensions revealed that a considerable proportion of the golf courses in Catalonia have had only a basic, static online presence and that the 18 -hole courses have undoubtedly been the most active. Those results align with the findings of applied research in various sectors indicating that websites are often static showcases of products and services that do not exploit web-based capacities for company-client interaction and thus do not foster bilateral client-organisation relations $[44,56,80]$.

Table 6. Additional functions (AF) indicators with percentages by type of golf course.

\begin{tabular}{lcccc}
\hline \multicolumn{1}{c}{ Additional Functions } & 18 Holes & 9 Holes & Total & V.C. and Sig. \\
\hline 1. Information safety & & & & \\
\hline AF 1.1- Privacy policy and legal notice & 74.1 & 50.0 & 67.6 & 0.228 \\
\cline { 2 - 5 } AF 1.2- Data protection laws & 66.7 & 30.0 & 56.8 & $0.329 *$ \\
AF 1.3- Secure website & 44.4 & 30.0 & 40.5 & 0.131 \\
\hline 2. Certifications. & & & & \\
\hline AF 2.1- Golf Environment Organization (GEO) certificate & 7.4 & 0 & 5.4 & 0.145 \\
\cline { 2 - 5 } AF 2.2- Environment management systems (EMS) & 0 & 0 & 0 & - \\
AF 2.3- Environmental certifications (ISO 14000) & 3.7 & 0 & 2.7 & 0.101 \\
AF 2.4- Other certifications & 0 & 0 & 0 & - \\
\hline 3. Mobile versions. & \multicolumn{3}{c}{0} \\
\hline AF 3.1- Link to the mobile version of the website & 100 & 10.0 & 75.7 & $0.932 * *$ \\
AF 3.2- Official golf course app & 11.1 & 10.0 & 10.8 & 0.016 \\
\hline
\end{tabular}

`Sig: 0.01; ${ }^{*}$ Sig: 0.05; ** Sig: 0.001 .

\subsection{Results of the eMICA}

Overall, results regarding the maturity of the websites in terms of commercial web applications suggest that the golf courses have room for improvement in adopting e-commerce (Table 7).

Table 7. Results of the extended model of internet commerce adoption (eMICA) by golf course type.

\begin{tabular}{ccccccc}
\hline & \multicolumn{2}{l}{ 18 Holes } & \multicolumn{2}{c}{ 9 Holes } & \multicolumn{2}{c}{ Total } \\
\hline Promotion (information) & & & & & & \\
\hline Level 1 Basic information & 27 & $100 \%$ & 10 & $100 \%$ & 37 & $100 \%$ \\
\hline Level 2 Rich information & 18 & $66.7 \%$ & 4 & $40 \%$ & 22 & $55 \%$ \\
\hline Provision (dynamic information) & & & & & & \\
\hline Level 1 Low level of interactivity & 16 & $59.2 \%$ & 4 & $40 \%$ & 20 & $50 \%$ \\
\hline Level 2 Medium level of interactivity & 14 & $51.8 \%$ & 2 & $20 \%$ & 16 & $40 \%$ \\
\hline Level 3 High level of interactivity & 4 & $14.8 \%$ & 0 & $0 \%$ & 4 & $10 \%$ \\
\hline Processing (functional maturity) & 4 & $14.8 \%$ & 0 & $0 \%$ & 4 & $10 \%$ \\
\hline
\end{tabular}

That only $10 \%$ of the websites attained Phase 3 and that the majority were situated in Phase 1 -the $50 \%$ mark was reached at Level 1 of Phase 2-indicates the low functional maturity of the golf courses in developing their websites. However, the results also indicate a shift from more static to more dynamic websites, marked by increasing levels of interactivity. In Phase 3 in particular, which contained 10\% of the evaluated websites, most of the sites, in addition to offering purchase processes and secure 
payment gateways, had communication mechanisms favouring client-company interactivity. By type, the websites for the 18-hole courses had the highest degree of interactivity and maturity- $14.8 \%$ were in the third phase-whereas no site for the nine-hole courses reached Phase 3.

\subsection{Results of the PCA}

After analysing the dimensions of the eMICA phases, we combined the two analytical methods to compare the presence and maturity of e-commerce on the golf courses' websites. That process involved conducting a PCA including all of the variables of both methods- that is, the four dimensions of the WCA and the six levels of the eMICA—such that both techniques were integrated.

Prior to interpreting the items and levels of each method, we calculated the means of the WCA items for each dimension based on the eMICA phases that they attained. Notably, most of the golf courses had attained the highest phase level (i.e., Level 3) without passing through the previous levels or phases; those courses are not included in Table 7. Put differently, some websites, especially for the nine-hole courses, attained the first phase (i.e., promotion) or the third phase (i.e., processing) without passing through the second one (i.e., provision).

Table 8 shows the relationships between the measurements of website maturity and content, including the number of golf courses that attained each eMICA phase (e.g., 6 of 37 attained Phase 2 whereas 20 attained Phase 3); the means of the items of each dimension of the WCA; the total of items by type of golf course; and the statistical significance ( ${ }^{\wedge} p<0.01,{ }^{*} p<0.05,{ }^{* *} p<0.001$ ) and power of the relation (the value of the Eta statistic) between having attained or not attained each phase of the eMICA and each of the content analysis dimensions.

Among the results, the dimension of information was related to Phase 1 of the eMICA $\left(\right.$ Eta $\left.=0.606^{* *}\right)$, whereas the dimension of e-commerce was strongly related to the attainment of Phase $3\left(\right.$ Eta $=0.947^{* *}$ ). Added to that, the websites that had passed through all of the phases generally had more items in all of the dimensions of the WCA. At the same time, of all 46 items of the WCA that the websites could exhibit, the ones for the 18-hole courses had significantly more than those for their nine-hole counterparts ( 25.9 vs. 16.3 , respectively; Eta $=0.698^{* *}$ ). The 18-hole courses that did not attain Phase 2 (i.e., provision) had an average of 24.7 of the items, whereas those that did attain Phase 2 had an average of 30 , for a difference in means that was also statistically significant.

Table 9 shows the weights of each of the two components extracted. Component 1 related to e-commerce and processing, whereas Component 2 related to information and low interactivity. Low eMICA levels are clearly related to the dimension of information, whereas high eMICA levels are clearly related to the other content analysis dimensions (Figure 2). However, though the dimension of communication predominated in Component 1, it had an important weight in Component 2 as well. By contrast, the intermediate interaction level (Level 2.2) predominated in Component 2, albeit with low weight $(<0.5)$. In integrating the two methods, no variables were rejected; even so, the total variance explained by the two components, $67.73 \%$, was relatively low but nevertheless sufficient and even reasonable considering the number of variables [81]. 
Table 8. Relationship between the eMICA phases attained, and the web content analysis dimensions, by golf course type (ANOVA).

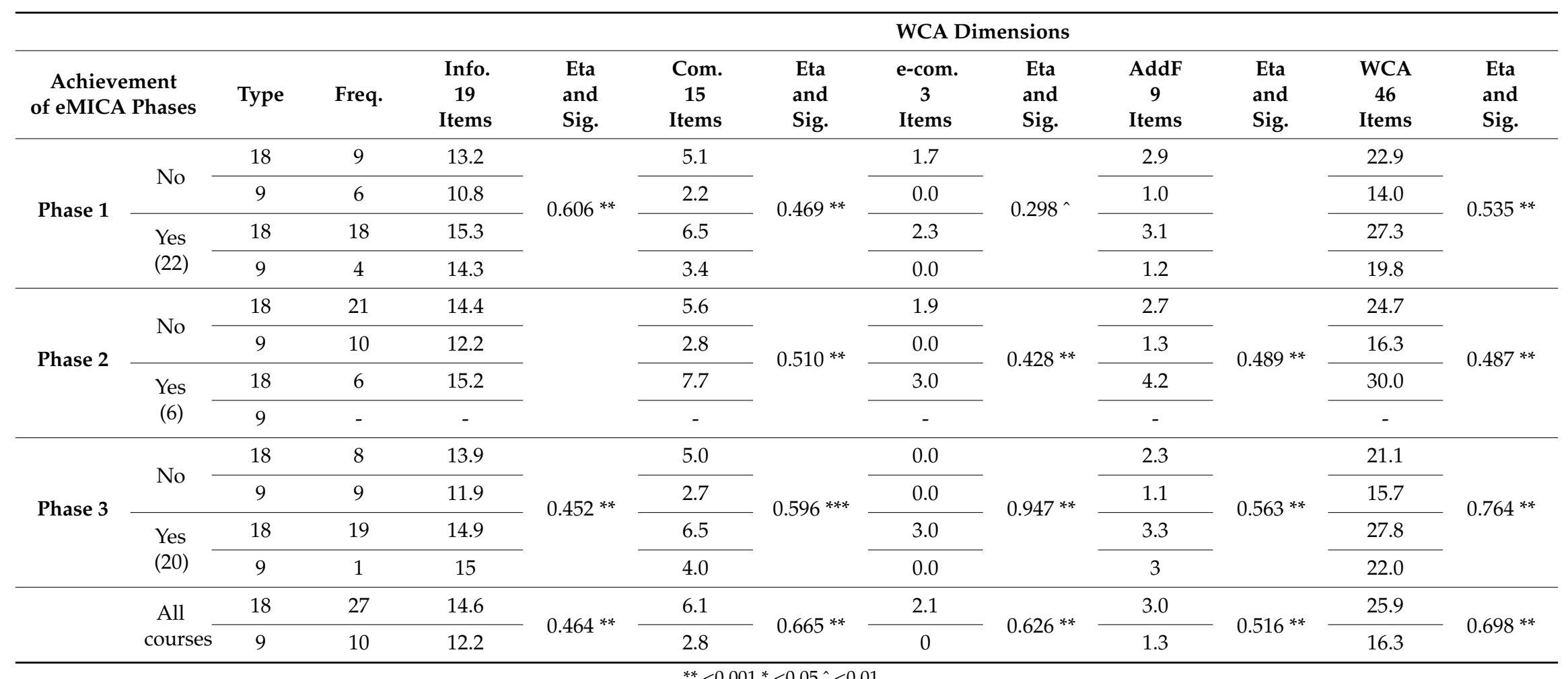

** $<0.001^{*}<0.05^{\wedge}<0.01$ 
Table 9. Matrix of the rotated components (Varimax).

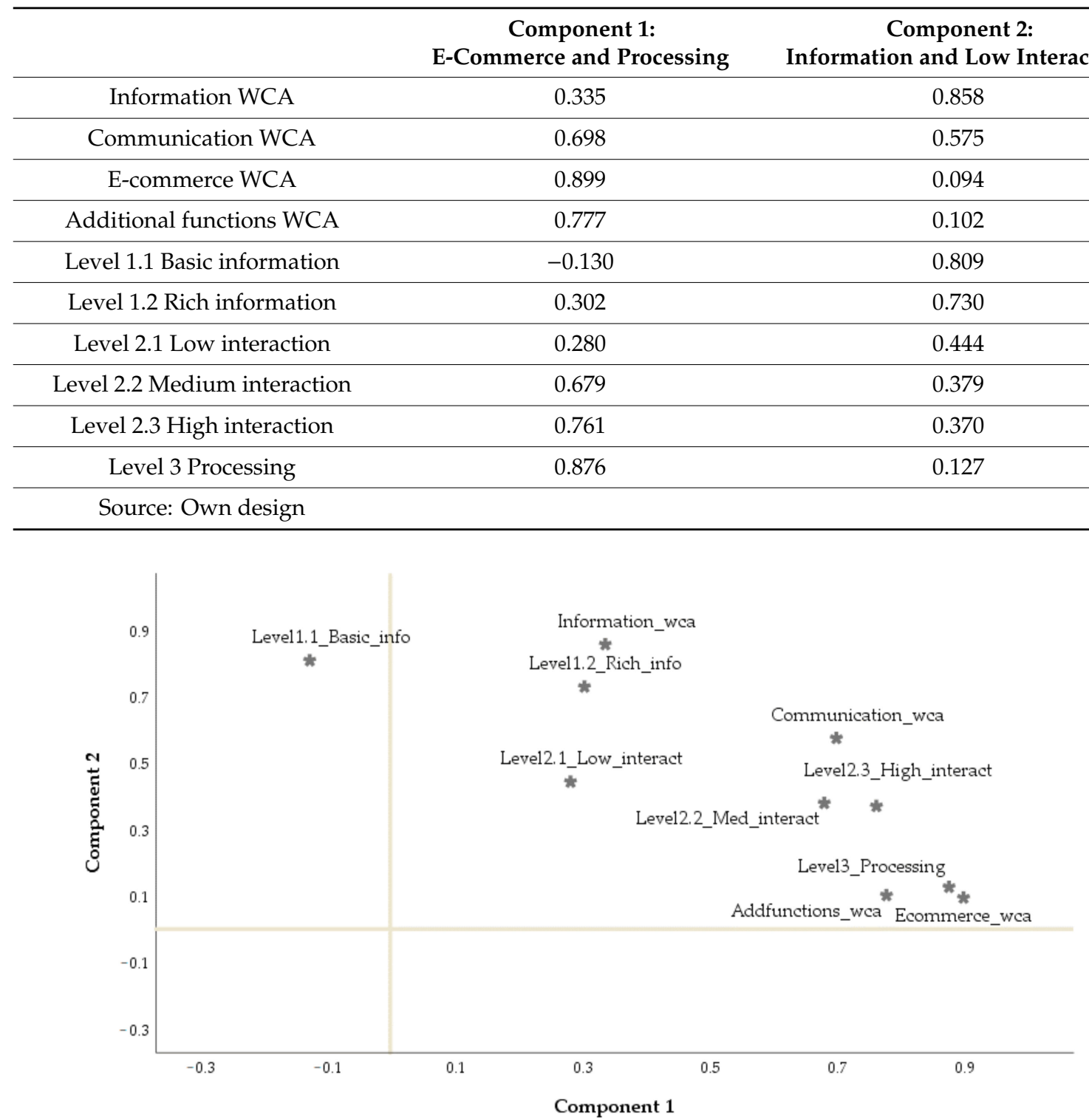

Figure 2. Principal component analysis of the web content analysis (WCA) and phases of the extended model of internet commerce adoption with Varimax rotation.

Having obtained the weights of the variables (i.e., phases of the eMICA phases and dimensions of the WCA) of the two extracted components, along with the means of the frequencies of each variable by type of golf course, we applied the following formulae to compare the online presence and e-commerce maturity of the two types of golf courses.

e-commerce and processing $=(0.698 \times$ communication $)+(0.899 \times$ e-commerce $)+$ $(-0.777 \times$ additional functions $)+(0.679 \times$ Level 2.2$)+(0.761 \times$ Level 2.3$)+(0.876 \times$ Level 3$)$

Information and low interaction $=(0.858 \times$ information $)+(0.809 \times$ Level 1.1 $)+$ $(0.730 \times$ Level 1.2) $+(0.444 \times$ Level 2.1$)$

Multiplying the results of both components integrates the two methods. Table 10 shows that the websites for the nine-hole golf courses contain far more information than e-commerce elements. We also observed that the sites for the 18-hole course were more complex (336.69), for they had higher levels of information, interactivity and electronic processing. In fact, the major difference between the 
two types of golf courses was in their electronic complexity (Component 1 ). The levels of information provided by the type of course, although lower on sites for the nine-hole courses, were quite similar. Whereas Component 1 was statistically significant by the type of golf course $(p<0.05)$, Component 2 was not.

Table 10. Results of the integrated eMICA and web content analysis by golf course type.

\begin{tabular}{cccc}
\hline & $\begin{array}{c}\text { E-commerce } \\
\text { and Processing }\end{array}$ & $\begin{array}{c}\text { Information } \\
\text { and Low Interaction }\end{array}$ & $\begin{array}{c}\text { Integrated } \\
\text { Model }\end{array}$ \\
\hline 18 Holes & 15.48 & 21.76 & 336.69 \\
\hline 9 Holes & 5.73 & 18.34 & 105.01 \\
\hline
\end{tabular}

\section{Discussion}

This section synthesises the results of applying the WCA and the eMICA in a bid to examine the websites of golf courses in Catalonia. Focusing first on the WCA, we observed that, as far as disseminating information is concerned, the golf courses have met the basic conditions for informing potential clients about their golfing and other facilities. For one, results in the dimension of communication suggest that businesses in the sports industry generally make limited use of interactive online tools to establish a dialogue with users. However, that dialogue would provide the golf courses with better knowledge of their clients and, thus, improve the services offered.

For another, although interaction is critical to the online presence of any company or organisation [82,83], our results indicate that the golf courses have significant work to do before they can take meaningful advantage of the possibilities offered by the internet. At the same time, the companies do have a presence on social and other media, which act as major veins of communication. By type, of course, 18-hole courses in our study were generally more active online, although their nine-hole counterparts have made it easy to share content with friends and contacts.

Next, concerning e-commerce, great differences emerged depending upon the type of golf course. Whereas the majority of websites for 18-hole courses had online reservation and payment systems, sites for nine-hole courses did not. Those results are consistent with previous findings concerning web content provided by golf courses [21,43].

Last, regarding additional functions, the presence of quality certifications on the websites was poor, and only sites for the 18-hole courses showed environmental certifications, if any. Of course, as research has shown, results in other fields such as gastronomy and social economics and even findings of snow sports facilities have been similar $[55,57,58]$. In any case, a minority of facilities represented by the websites that we assessed have reported information on environmental or quality certifications.

In all, applying the eMICA has shown us that golf courses in Catalonia have not reached maturity in their e-commerce activities. Meanwhile, according to the WCA combined with the eMICA, the online presence of most of the courses is at an intermediate stage of development- that is, used primarily as a tool for communication. The use of the full range of online business possibilities is thus clearly underdeveloped among the courses, especially the nine-hole ones.

\section{Conclusions}

Because ICTs bear great influence on sports organisations in general and on the golf industry in particular, the management and marketing of golf courses have to adapt in order to take advantage of the benefits offered by the internet in all of its dimensions.

The research undertaken revealed that the websites of golf courses present high levels of communication in all aspects related to static information, meaning information about location, facilities, access routes and lessons, among other things. However, the degree of communication is far lower for indicators that offer nonstatic information and functions, including weather conditions, content-sharing applications, links to blogs and social media. That type of information can be very 
useful, however, for it enhances the perceived credibility of organisations and the trust that clients feel towards them [84].

Golf courses exert a high touristic and economic impact on their localities. However, in Catalonia, the opportunities offered online to promote golf and its associated facilities are not being fully exploited. Many websites for golf courses neither provide information in multiple languages nor publicise local tourist resources, both of which can be key decision-making factors for tourists when selecting or booking travel destinations. Beyond that, environmental sustainability policies are not being publicised, either. Nevertheless, environmental policies can be decisive for clients, many of whom are increasingly aware of sustainability and climate change.

Our results also show a differentiated degree of online presence depending on the type of golf course. Websites for 18-hole courses have higher interactivity, offer more information and are better adapted to conduct transactions and provide internet security than the websites of the nine-hole courses, which are far behind in all stages and at all levels analysed.

From the standpoint of methodology, we have additionally demonstrated that our integrated model is usable and can help to systematically and reliably assess content and the degree of e-commerce adoption, which provides an understanding of the stage of development of golf courses and what aspects need to be introduced or improved.

As for managerial recommendations, golf course management should first of all be aware that their market segment is technologically advanced, has high purchasing power and is accustomed to immediate responses [85]. Their company websites are often their potential clients' first contact with the organisation and thus key to image formation. Golf course managers should take the proposed model into account so that their websites can match the expectations of the golf-playing consumer profile, which stands to greatly increase visitor and booking numbers and client-company interaction. In turn, they should also create synergies with tourist destination managers; they might carry out joint promotional campaigns to position the area as a specific destination for golf tourism. After all, golf courses can be important poles of attraction that can create large tourist flows by offering an attractive complementary activity to others offered by the destination. At the same time, the results show that only slightly more than half of the golf courses analysed have mentioned data protection laws on their websites, which is of course highly recommended in order to communicate that the company complies with the law.

A limitation of our study was that we conducted our analysis at a specific moment, and because websites for golf courses may change at any time, the results from one moment to the next may change as well. Another important limitation was the number of websites analysed. Although they represented all golf courses registered in Catalonia, it is necessary to expand the number of websites analysed. A proposed future line of research would thus be to extend the analysis to golf courses in other regions and countries to collect more data and compare the results. In addition, personal interviews might be conducted with golf course managers to identify the chief barriers that they encounter in advancing their online presence and improving their interactivity with clients.

Author Contributions: Conceptualization, N.D. and E.C.-F.; methodology, N.D. and B.F.-R.; validation, N.D., E.C.-F. and B.F.-R.; formal analysis, N.D., E.C.-F. and B.F.-R.; investigation, N.D., E.C.-F. and B.F.-R.; data curation, N.D. and B.F.-R.; writing-Original draft preparation, E.C.-F. and N.D.; writing-Review and editing, B.F.-R.; supervision, E.C.-F.; project administration, N.D.; funding acquisition, B.F.-R. Authorship must be limited to those who have contributed substantially to the work reported. All authors have read and agreed to the published version of the manuscript.

Funding: This work was supported by the Spanish Ministry of Economy, Industry and Competitiveness (Grant I.D.: TURCOLAB ECO2017-88984-R).

Acknowledgments: The authors acknowledge the support of the Catalan Government for the accreditation as Consolidated Research Group TURESCO (2017 SGR 49). Laura Puig-Prim is also thanked for the work done in data collection.

Conflicts of Interest: The authors declare no conflict of interest. 


\section{References}

1. Laudon, K.C.; Traver, C.G. E-Commerce: Business, Technology, Society; Pearson: Harlow, UK, 2017.

2. Alam, S.S.; Nor, N.G.M.; Ali, M.H.; Omar, N.A.; Wel, C.A.C. Relationship between entrepreneur's traits and cloud computing adoption among malay-owned SMEs in Malaysia. Cuad. Gest. 2018, 18, 115-132. [CrossRef]

3. Calvo-Porral, C.; Nieto-Mengotti, M. The moderating influence of involvement with ICTs in mobile services. Span. J. Mark. ESIC 2019, 23, 25-43. [CrossRef]

4. Eze, S.C.; Chinedu-Eze, V.C.; Bello, A.O. Determinants of dynamic process of emerging ICT adoption in SMEs-actor network theory perspective. J. Sci. Technol. Policy Manag. 2019, 10, 2-34. [CrossRef]

5. Kijek, T.; Kijek, A. Is innovation the key to solving the productivity paradox? J. Innov. Knowl. 2019, 4, 219-225. [CrossRef]

6. Dangi, M.R.M.; Ismail, A.H.; Johari, R.J.; Noor, R.M. SME's Internationalization Initiatives: Business \& Growth Strategy ICT and Technology. Int. J. Account. Financ. Bus. 2018, 3, 63-75.

7. Fink, C.; Mattoo, A.; Neagu, I.C. Assessing the impact of communication costs on international trade. J. Int. Econ. 2005, 67, 428-445. [CrossRef]

8. Biagi, F.; Falk, M. The impact of ICT and e-commerce on employment in Europe. J. Policy Model. 2017, 39, 1-18. [CrossRef]

9. Mikalef, P.; Pateli, A. Information technology-enabled dynamic capabilities and their indirect effect on competitive performance: Findings from PLS-SEM and fsQCA. J. Bus. Res. 2017, 70, 1-16. [CrossRef]

10. Piccoli, G.; Lui, T.-W. The competitive impact of information technology: Can commodity IT contribute to competitive performance. Eur. J. Inf. Syst. 2014, 23, 616-628. [CrossRef]

11. Hofacker, C.F.; Belanche, D. Eight social media challenges for marketing managers. Span. J. Mark. ESIC 2016, 20, 73-80. [CrossRef]

12. Burstein, A.; Vogel, J. International trade, technology, and the skill premium. J. Polit. Econ. 2017, 125, 1356-1412. [CrossRef]

13. Ming, D.; Xiao, C.; Han, J. Effect of Interaction between Exporter's Technology Level and Importer's Protection of IPR on Exporter's Trade: Evidences from China's Foreign Trade. Technol. Econ. 2017, 5, 1-13.

14. Cristobal-Fransi, E.; Martín, E.; Daries, N. Behavioral Analysis of Subjects Interacting with Information Technology: Categorizing the behavior of e-consumers. Int. J. Serv. Technol. Manag. 2015, 21, 163-182. [CrossRef]

15. FRONTUR-INE. Estadística de Movimientos Turísticos en Frontera [Tourist Movement on Borders]. Available online: https://www.ine.es/ (accessed on 15 June 2020). (In Spanish)

16. EGATUR-INE. Encuesta de Gasto Turístico [Tourism Spending Survey]. Available online: https://www.ine.es/ (accessed on 11 September 2020). (In Spanish)

17. World Travel and Tourism Council. Economic Impact of Tourism. Available online: https://www.wttc.org/ economic-impact/ (accessed on 11 September 2020).

18. Aymerich, F.; Anabitarte, J.; Golf Business Partners. El Impacto Económico del Golf en España [The Economic Impact of Golf in Spain]. Available online: https://www.rfegolf.es/CompetenciaPaginas/NewsDetails.aspx? NewsId=7012 (accessed on 11 September 2020). (In Spanish)

19. IAGTO (International Association of Golfing Tour Operators). Global Golf Tourism Market. Available online: https://www.iagto.com/pressrelease/index (accessed on 11 September 2020).

20. Sheets, B.H.; Roach-Humphreys, J.; Johnston, T. Turnaround Strategy: Overview of the Business and Marketing Challenges Facing the Golf Industry and Initiatives to Reinvigorate the Game. Bus. Educ. Innov. J. 2016, 8, 161-171.

21. Ciurana, J.T.P.; Del Campo-Gomis, F.J.; Gimenez, F.V.; Campos, D.P.; Torres, A.A. Analysis of the efficiency of golf tourism via the Internet. Application to the Mediterranean countries. Curr. Issues Tour. 2015, 18, 595-608. [CrossRef]

22. López-Bonilla, L.M.; Reyes-Rodríguez, M.D.C.; López-Bonilla, J.M. Golf tourism and sustainability: Content analysis and directions for future research. Sustainability 2020, 12, 3616. [CrossRef]

23. Enz, C.A.; Canina, L. Competitive pricing in the golf industry. J. Revenue Pricing Manag. 2017, 16, 139-153. [CrossRef]

24. Madrigal, M.A.; Lara, J.A.S. Golf tourism in southern Europe: A potential market. Stud. Appl. Econ. 2019, 37, 64-79. 
25. Sweeney, K. Golf Business and Management: A Global Introduction. J. Sport Manag. 2018, 32, $316-317$. [CrossRef]

26. Hudson, S.; Hudson, L. Golf Tourism; Goodfellow Publishing: Oxford, UK, 2010.

27. Song, H.M.; Kim, K.S.; Yim, B.H. The mediating effect of place attachment on the relationship between golf tourism destination image and revisit intention. Asia Pac. J. Tour. Res. 2017, 22, 1182-1193. [CrossRef]

28. Butler, R.W. Contributions of tourism to destination sustainability: Golf tourism in St Andrews, Scotland. Tour. Rev. 2019, 74, 235-245. [CrossRef]

29. Lee, J.J.; Kyle, G.T.; Scott, D. The mediating effect of place attachment on the relationship between festival satisfaction and loyalty to the festival hosting destination. J. Travel Res. 2012, 51, 754-767. [CrossRef]

30. Yoon, Y.; Uysal, M. An examination of the effects of motivation and satisfaction on destination loyalty: A structural model. Tour. Manag. 2005, 26, 45-56. [CrossRef]

31. Geissler, G.L. An examination of the Golf vacation package-purchase decision: A case study in the US Gulf Coast region. J. Hosp. Leis. Mark. 2005, 13, 65-82. [CrossRef]

32. Hutchinson, J.; Wang, Y.; Lai, F. The impact of satisfaction judgment on behavioral intentions: An investigation of golf travelers. J. Vacat. Mark. 2010, 16, 45-59. [CrossRef]

33. Hennessey, S.M.; Macdonald, R.; MacEachern, M. A framework for understanding golfing visitors to a destination. J. Sport Tour. 2008, 13, 5-35. [CrossRef]

34. Park, J.; Morrison, A.M.; Wu, B.; Kong, Y. Korean Golf Tourism in China: Place, Perception and Narratives. Sustainability 2018, 10, 1055. [CrossRef]

35. Petrick, J.F. Are loyal visitors desired visitors? Tour. Manag. 2004, 25, 463-470. [CrossRef]

36. Tassiopoulos, D.; Haydam, N. Golf tourists in South Africa: A demand-side study of a niche market in sports tourism. Tour. Manag. 2008, 29, 870-882. [CrossRef]

37. Humphreys, C. Understanding how sporting characteristics and behaviours influence destination selection: A grounded theory study of golf tourism. J. Sport Tour. 2014, 19, 29-54. [CrossRef]

38. Stebbins, R.A. Leisure as not work: A (far too) common definition in theory and research on free-time activities. World Leis. J. 2018, 60, 255-264. [CrossRef]

39. Kim, J.H.; Ritchie, B.W. Motivation-based typology: An empirical study of golf tourists. J. Hosp. Tour. Res. 2012, 36, 251-280. [CrossRef]

40. Gibson, H.J.; Pennington-Gray, L. Insights from role theory: Understanding golf tourism. Eur. Sport Manag. Q. 2005, 5, 443-468. [CrossRef]

41. Higham, J.; Hinch, T. Sport Tourism Development, 3rd ed.; Channel View Publications: Bristol, UK, 2018.

42. Powers, R.L.; Tabibzadeh, K. An Exploratory Study of Web Use by the Golf Course Industry. Int. J. Acad. Bus. World 2010, 4, 29-32.

43. Afonso Dias, J.; Martínez-López, F.J. The use of the internet in golf course promotion: A comparative analysis of the golf course web pages of the Algarve, Andalusia and Florida. Rev. Tur. Desenvolv. 2011, 16, 73-84.

44. García-Tascón, M.; Pradas-García, M. Does the transparency of the websites can help in attracting customers? Analysis of the golf courses in Andalusia. Intang. Cap. 2016, 12, 805-821. [CrossRef]

45. Brooksbank, R.; Garland, R.; Werder, W. Strategic marketing practices as drivers of successful business performance in British, Australian and New Zealand golf clubs. Eur. Sport Manag. Q. 2012, 12, 457-475. [CrossRef]

46. Garland, R.; Brooksbank, R.; Werder, W. Strategic marketing's contribution to Australasian golf club performance. Sport Bus. Manag. Int. J. 2011, 1, 138-154. [CrossRef]

47. Pereira, R.; Correia, A.; Schutz, R.L. Destination brand personality: Searching for personality traits on golf-related websites. Anatolia Int. J. Tour. Hosp. Res. 2014, 25, 387-402. [CrossRef]

48. Roigb, E.M.-; Rosellb, B.F.-; Daries, N.; Cristóbal-Fransi, E. Measuring Gastronomic Image Online. Int. J. Environ. Res. Public Health 2019, 16, 4631. [CrossRef]

49. Abdallah, S.; Jaleel, B. Website appeal: Development of an assessment tool and evaluation framework of e-marketing. J. Theor. Appl. Electron. Commer. Res. 2015, 10, 45-62. [CrossRef]

50. Camprubí, R.; Coromina, L. Content analysis in tourism research. Tour. Manag. Perspect. 2016, 18, 134-140. [CrossRef]

51. Herring, S.C. Web content analysis: Expanding the paradigm. In International Handbook of Internet Research; Springer: Dordrecht, The Netherlands, 2009; pp. 233-249. 
52. Law, R. Evaluation of hotel websites: Progress and future developments. Int. J. Hosp. Manag. 2019, 76, $2-9$. [CrossRef]

53. Benbunan-Fich, R. Using protocol analysis to evaluate the usability of a commercial web site. Inf. Manag. 2001, 39, 151-163. [CrossRef]

54. Chiou, W.-C.; Lin, C.-C.; Perng, C. A strategic framework for website evaluation based on a review of the literature from 1995-2006. Inf. Manag. 2010, 47, 282-290. [CrossRef]

55. Cristobal-Fransi, E.; Daries-Ramon, N.; Mariné-Roig, E.; Martin-Fuentes, E. Implementation of Web 2.0 in the snow tourism industry: Analysis of the online presence and e-commerce of ski resorts. Span. J. Mark. ESIC 2017, 21, 117-130. [CrossRef]

56. Álvarez Díaz, Y. La Orientación al Mercado en el Sector Turístico Con el Uso de las Herramientas de la Web Social, Efectos en Los Resultados Empresariales [Market Orientation in the Tourism Sector with Social Web Tools, Effects on Business Results]. Ph.D. Thesis, University of Cantabria, Santander, Spain, 2014. Available online: http://hdl.handle.net/10902/5018 (accessed on 28 September 2020).

57. Cristobal-Fransi, E.; Montegut-Salla, Y.; Ferrer-Rosell, B.; Daries, N. Rural cooperatives in the digital age: An analysis of the Internet presence and degree of maturity of agri-food cooperatives'e-commerce. J. Rural Stud. 2020, 74, 55-66. [CrossRef]

58. Daries, N.; Cristobal-Fransi, E.; Ferrer-Rosell, B.; Marine-Roig, E. Maturity and development of high-quality restaurant websites: A comparison of Michelin-starred restaurants in France, Italy and Spain. Int. J. Hosp. Manag. 2018, 73, 125-137. [CrossRef]

59. Davies, M.; Gray, D. Exploring the information source preferences among Canadian adult golf league members. J. Amat. Sport 2016, 2, 1-28. [CrossRef]

60. Hasley, J.P.; Gregg, D.G. An exploratory study of website information content. J. Theor. Appl. Electron. Commer. Res. 2010, 5, 27-38. [CrossRef]

61. Lee, J.K.; Morrison, A.M. A comparative study of web site performance. J. Hosp. Tour. Technol. 2010, 1, 50-67. [CrossRef]

62. Lim, H.; Widdows, R.; Hooker, N.H. Web content analysis of e-grocery retailers: A longitudinal study. Int. J. Retail. Distrib. Manag. 2009, 37, 839-851. [CrossRef]

63. Wanless, E.A.; Petersen, J.C.; Pursglove, L.K.; Desmond, L.; Judge, L.W. Accessible Golf Courses: Web-based Accommodation Communication. Phys. Educ. 2018, 75, 816-834. [CrossRef]

64. Neuendorf, K.A. The Content Analysis Guide Book; Sage Publications: London, UK, 2016.

65. Burgess, L.; Cooper, J. The Status of Internet Commerce in the Manufacturing Industry in Australia: A survey of Metal Fabrication Industries. In Proceedings of the Second CollECTeR Conference on Electronic Commerce, Sydney, NSW, Australia, 10 October 1998; pp. 65-73.

66. Burgess, L.; Sargent, J.P.; Cooper, J.; Cerpa, N. A comparative analysis of the use of the Web for destination marketing by regional tourism organisations in Chile and the Asia Pacific. In Collaborative Electronic Commerce Technology and Research; Universidad de Talca: Talca, Chile, 2005.

67. Burgess, S. Representing small business web presence content: The web presence pyramid model. Eur. J. Inf. Syst. 2016, 25, 110-130. [CrossRef]

68. Burgess, L.; Parish, B.; Alcock, C. To what extent are regional tourism organisations (RTOs) in Australia leveraging the benefits of web technology for destination marketing and eCommerce? Electron. Commer. Res. 2011, 11, 341-355. [CrossRef]

69. Daries, N.; Cristobal-Fransi, E.; Mariné-Roi, E. Deployment of restaurants websites' marketing features: The case of Spanish Michelin-starred restaurants. Int. J. Hosp. Tour. Adm. 2019, 20, 249-280.

70. Doolin, B.; Burgess, L.; Cooper, J. Evaluating the use of the Web for tourism marketing: A case study from New Zealand. Tour. Manag. 2002, 23, 557-561. [CrossRef]

71. Lin, D.; Zhou, Z.; Guo, X. A study of the website performance of travel agencies based on the EMICA model. J. Serv. Sci. Manag. 2009, 3, 181-185. [CrossRef]

72. Ting, P.H.; Wang, S.T.; Bau, D.Y.; Chiang, M.L. Website evaluation of the top 100 hotels using advanced content analysis and eMICA model. Cornell Hosp. Q. 2013, 54, 284-293. [CrossRef]

73. Cristobal-Fransi, E.; Daries, N.; Serra-Cantallops, A.; Ramón-Cardona, J.; Zorzano, M. Ski Tourism and Web Marketing Strategies: The Case of Ski Resorts in France and Spain. Sustainability 2018, 10, 2920. [CrossRef]

74. Daries, N.; Cristóbal Fransi, E.; Martín Fuentes, E.; Mariné Roig, E. E-commerce adoption in mountain and snow tourism: Analysis of ski resort web presence through the EMICA model. Cuad. Tur. 2016, 37, 483-487. 
75. Girginov, V.; Taks, V.M.; Boucher, B.; Martyn, S.; Holman, M.; Dixon, J. Canadian national sport organizations' use of the web for relationship marketing in promoting sport participation. Int. J. Sport Commun. 2009, 2 , 164-184. [CrossRef]

76. Schmidt, S.; Serra Cantallops, A.; Dos Santos, C.P. The characteristics of hotel websites and their implications for website effectiveness. Int. J. Hosp. Manag. 2008, 27, 504-516. [CrossRef]

77. Marimon, F.; Vidgen, R.; Barnes, S.J.; Cristóbal-Fransi, E. Purchasing behaviour in an online supermarket: The applicability of E-S-QUAL. Int. J. Mark. Res. 2010, 52, 111-129. [CrossRef]

78. Ratten, V. Sport innovation management: Towards a research agenda. Innovation 2016, 18, 238-250. [CrossRef]

79. Breitbarth, T.; Kaiser-Jovy, S.; Dickson, G. Global golf business and management. In Golf Business and Management; Routledge: London, UK, 2017; pp. 1-18.

80. Kim, J.H.; Kim, M.; Lennon, S.J. E-Service Performance of Apparel E-Retailing Websites: A Longitudinal Assessment. Int. J. Serv. Sci. Manag. Eng. Technol. 2018, 9, 24-40. [CrossRef]

81. Hair, J.; Anderson, R.E.; Black, W.; Tatham, R.L. Multivariate Data Analysis: A Global Perspective, 7th ed.; Prentice-Hall: London, UK; Upper Saddle River, NJ, USA, 2009.

82. Anwar, A.; Waqas, A.; Zain, H.M.; Kee, D.M.H. Impact of Music and Colour on Customers' Emotional States: An Experimental Study of Online Store. Asian J. Bus. Res. 2020, 10, 104. [CrossRef]

83. Ijaz, M.F.; Rhee, J. Constituents and Consequences of Online-Shopping in Sustainable E-Business: An Experimental Study of Online-Shopping Malls. Sustainability 2018, 10, 3756. [CrossRef]

84. Nilashi, M.; Ibrahim, O.; Yadegaridehkordi, E.; Samad, S.; Akbari, E.; Alizadeh, A. Travelers decision making using online review in social network sites (2018), A case on TripAdvisor. J. Comput. Sci. 2018, 8, 168-179. [CrossRef]

85. Costa, S.; Sousa, B. Exploratory study of consumer behavior and profile in specific tourism contexts: Golf tourism in Northern Portugal. Tour. Hosp. Int. J. 2019, 12, 13-31.

Publisher's Note: MDPI stays neutral with regard to jurisdictional claims in published maps and institutional affiliations.

(C) 2020 by the authors. Licensee MDPI, Basel, Switzerland. This article is an open access article distributed under the terms and conditions of the Creative Commons Attribution (CC BY) license (http://creativecommons.org/licenses/by/4.0/). 